Даница Савић

Универзитетска библиотека

у Крагујевцу

danica.savic@uni.kg.ac.rs
Прегледни рад

УДК 028.8:615.85(091)

https://doi.org/10.18485/bibliotekar.2021.63.2.1

\title{
НАСТАНАК, РАЗВОЈ И ЗНАЧАЈ БИБЛИОТЕРАПИЈЕ
}

Сажетак: Рад настоји да синтетише доступне текстове који проблематизују библиотерапију као помоћни терапеутски метод, који своју научну заснованост добија тек у 20. веку. Такође, сем дефинисања самог појма, настоји се излистати значај библиотерапије на преображај личности, као и улога терапеута/библиотекара у самом процесу лечења књигом. У раду се истичу резултати соционике која додатно употпуњује библиотерапеутски метод сазнањима о типовима читалаца заснованим на Јунговој типологији личности. Попут типова личности, у оквиру библиотерапије разликују се и типови књига које омогућавају индивидуализован приступ у процесу лечења. Предочене су и описане врсте библиотерапије - институционална, клиничка и развојна библиотерапија - које, у земљама у којима се примењују, заједнички спроводе медицински и библиотечки стручњаци. Предочен је и многоструко позитиван учинак библиотерапије, од психокорекције емоционалног стања, преко стваралачких и адаптивних навика, до усавршавања комуникације са околином. Такође, побројани су домаћи аутори који су до сада дали допринос изучавању ове теме.

Кључне речи: појам библиотерапије, институционална библиотерапија, клиничка библиотерапија, развојна библиотерапија, соционика, типови читалаца, типови књига, литература за библиотерапију, делотворност библиотерапије.

\section{Осврт на појам и историју библиотерапије}

Појам библиотерапија, настао од грчких речи biblion (књига) и therapeia (лечење), данас наилази на онолико дефиниција колико је теоретичара који се њиме баве, па су стога дефиниције библиотерапије бројне, у зависности од аспеката са којих се феномен читања посматра. Неке од дефиниција истичу позитивне ефекте читања у лечењу психичких болести, 
док, са друге стране, постоје дефиниције које истичу интерактивни однос између реципијента и литературе погодне за лични раст и развој личности. Оно у чему су сагласне све дефиниције јесте да библиотерапија представља специфичан облик психотерапије, тј. да је у питању јединствена дисциплина поникла на спрези психијатрије, психотерапије и библиотекарства. Из садејства ових трију дисциплина произилазе и други називи за библиотерапију - библиопсихотерапија, ${ }^{1}$ либротерапија, ${ }^{2}$ књиготерапија, ${ }^{3}$ либропсихотерапија, ${ }^{4}$ терапија читањем.

Осврнемо ли се на историју цивилизације, лако је уочити готово сакралан положај књиге, односно библиотека које су се налазиле при светилиштима или уз краљевске палате. О веровању у божанско порекло књиге сведоче натписи на библиотекама старог света, па је тако нпр. изнад улаза у неке библиотеке стајао натпис лек за gушу или месйо за исцельене gyше као подсећање на сакралност књиге и места на коме се она чува. Питагора је у исцелитељске сврхе користио стихове. Платон је указивао на важно место књижевности ради одржања психичке хармоније. Позната је Аристотелова дефиниција трагедије у којој се упућује на катарзу ${ }^{5}$ - $\bar{p} о$ чишћаваюе афекай - кроз осећање страха и сажаљења које драмско дело изазива код гледалаца. У средњем веку, прве црквене библиотеке лечиле су књигама религиозне тематике нудећи својим корисницима духовни мир и наду у искупљење. Епоха ренесансе интензивира примену библиотерапије у сврху излечења. Научно утемељење библиотерапија добија тек у 20. столећу - Семјуел Кротерс 1916. године први пут употребљава појам библиотерапије да би означио метод који претпоставља да се читањем литературе може повољно утицати на понашање и превазићи стрес. У СССР-у, двадесетих година прошлог века, вршена су истраживања о благотворном дејству књиге на здравље. „Активно се користила библиотерапија у медицинским библиотекама. Лекари су видели свој конкретан задатак 'лечења књигом' у томе да одаберу литературу у складу са дијагнозом и ефекат лечења заснивао се на томе да пацијент препозна

https://covers4all.ru/mk/krovotecheniya/chitat-onlain-moi-alkogolizm/ (приступљено 23. 10. 2021).

2 https://hr.pour-femme.org/8887667-book-therapy-a-book-will-save-our-lives-find-out-how (приступљено 23. 10. 2021).

Исто.

https://hr.griego-medical.com/vzaimosvjaz-psihicheskih-sostojanij-i-povedenija.htm (приступљено 23. 10. 2021).

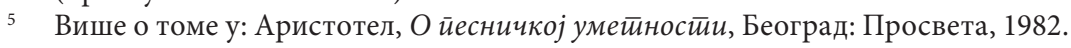


проблем који се одражава у уметничком делу, у саветима да прати те примере сличних 'ситуација', а што је сличнија ситуација описана у књизи, или што је сличнији карактер пацијента карактеру из књиге, то је јачи терапеутски ефекат."6 Тридесетих година 20. века, медицински стручњаци у САД долазе до истоветних закључака о ефективности библиотерапије. Током Другог светског рата, као и након њега, библиотерапија се показала учинковитом у рехабилитацији рањених војника, што је довело до формирања библиотерапијских група у установама за психијатријско лечење. Са друге стране, социјални радници, такође, увиђају делотворност библиотерапијског лечења што условљава појаву групних третмана и терапија књигом. „Америчко библиотечко удружење 1966. године је прихватило дефиницију да је библиотерапија употреба бираних материјала за читање у терапеутске и едукативне сврхе у медицини и психијатрији."7 Све ово доводи до тога да у последњим деценијама протеклог века библиотерапија постаје признати терапеутски метод.

Пракса америчких психијатара је да у појединим случајевима, уместо медикамената, као терапију препоручују читање одређене књиге. Метод се показао ефикасним у терапији психосоматских поремећаја. Истовремено, делотворност библиотерапије посведочена је у лечењу кардиолошких и неуролошких тегоба какве су повишен крвни притисак, тахикардија или мигрена. „У Великој Британији, библиотерапеути, по посебној методологији, прописују 'индивидуалне рецепте' које књиге читати према узрасту пацијента и врсти тегоба. Пацијентима који покажу жељу и вољу за читањем, лекари препоручују и одабране књиге и приручнике о самопомоћи и кроз одређене савете и вежбе идентификације, пројекције, катарзе и увида уче их да помогну сами себи."8 Терапеутски ефекат код примене терапије читањем заснива се на постизању олакшања и оздрављења психофизичког стања човека упливом у његову емоционалну раван. У данашње време парадигме библиотерапије нису уједначене, али је свакако да постоји тенденција истраживања и теоретизовања овог вида терапије. У званичној науци изостаје једнообразна дефиниција библиотерапије, али већина стручњака сагласна је у томе да је у питању „наука на граници медицине и

\footnotetext{
Н. В. Аверјанов, „Лек за душу: примена библиотерапије у библиотеци”, превод Гордана Стевић, Корак библиоиекее 2, 2 (2017): 129-130.

7 Љиљана Симић, „Улога библиотеке у библиотерапији”, http://www.vma.mod.gov.rs (преузето 10. 8. 2021).
}

8 Исто. 
библиотекарства, повезана са активним увођењем човека у читање да би променио и разрешио своје личне проблеме". 9

\section{Врсте библиотерапије и њихова примена}

Лечење књигом данас представља економичан и делотворан чинилац психотерапије. Поникла на основама психоанализе, библиотерапија у својој примени код читаоца иницира ияенйификацију, ӣројекцију, ка$\bar{u} а р з у$ и вй $^{10}$ као развојне ступњеве на путу ка оздрављењу. У остваривању резултата примене овог начина психолошког и душевног исцељења неопходно је да, поред стручњака из домена психијатрије/психотерапије, учествује и библиотекар, за кога је пожељно да, сем доброг познавања своје делатности, поседује и знања из књижевности. Синтеза делатности које чине библиотерапију доприноси остваривању њених циљева.

„Библиотерапија се користи за следеће сврхе:

1. за испољавање индивидуалне самосвести;

2. омогућава човеку да боље схвати своје понашање и мотивацију;

3. помаже формирању адекватне самооцене;

4. помаже човеку да дефинише своје интересе и склоности;

5. олакшава последице стреса;

6. да покаже човеку да није први који се суочио са неким проблемом;

7. да покаже човеку да постоје различите варијанте решавања датог проблема;

8. да помогне човеку да слободније размотри проблем;

9. да помогне човеку да испланира исправан пут деловања у решавању проблема;

10. да изађе на пут самосвести, самореализације и, на крају крајева, самоактуелизације, да достигне психолошку зрелост."11

9 Н. В. Аверјанов, „Лек за душу: примена библиотерапије у библиотеци”, Корак библиотеке, превод Гордана Стевић, Корак библиотеке 2, 2 (2017): 130.

10 Видети: Маја Раденовић, „Библиотерапија као едукативна и терапијска алатка и приказ портретисања психолошких феномена у једном књижевном делу, са посебним освртом на депресију”. Тимочки меgицински іласник 40, 2 (2015): 106-110.

11 Наталија Тимовна Оганесјан, „Библиотерапија као средсто самоактуелизације психичких стања", у Библиоиекка као оїлеgало Васељене, приредио Добрило Аранитовић (Београд: Службени гласник, 2009), 534. 
Свакако је да библиотерапија треба да има учинак олакшања на психофизичко стање човека. Идентификација са прочитаним, промишљање и анализа парадигме фикционалне стварности треба да доведу до преображаја личности. Три су врсте библиотерапије - институционална, клиничка и развојна. Институционална библиотерапија се искључиво спроводи код хоспитализованих особа, реализује се као индивидуална или групна терапија којом управља тим састављен од медицинских стручњака и библиотекара. „Улога библиотеке одвија се кроз помоћ у организацији и вођењу фонда, давању приступа литератури према лекарској препоруци и сл. Институционална терапија примењује се само у библиотекама болничких институција чије се особље едукује за такве задатке." 12 Један од позитивних примера реализације библиотерапије у свету је експериментални пројекат у Великој Британији. Наиме, у појединим градовима, библиотекари су похађали едукативне програме за рад са психичким болесницима, а фонд који се користио током овог експеримента брижљиво је саставио тим медицинских стручњака и библиотекара. Поред књижне грађе, одабрани фонд је садржао и некњижну грађу о одређеним психичким тегобама или грађу којој је сврха да пружи самопомоћ. Прописани материјали, намењени специфичној врсти корисника, били су доступни за коришћење и другим члановима који су са „рецептом” долазили у библиотеку. Овај облик терапије не искључује примену медикамената, али свакако је да представља део терапије без нежељених дејстава, јер пацијенти до побољшања долазе властитом снагом. За разлику од институционалне библиотерапије која је погодна за пацијенте дијагностикованих средњих и лакших психичких болести, клиничка библиотерапија се сматра прилагодљивијим методом који заједнички спроводе психијатри, социјални радници и библиотекари. Клиничка библиотерапија се спроводи као групна терапија која, добровољно или присилно, укључује особе код којих постоје емоционални проблеми или проблеми у понашању. Такође, опсег њене примене обухвата и особе оболеле од тешких болести и код њих се спроводи у циљу превазилажења негативног психичког стања. У спровођењу клиничке библиотерапије улога библиотекара је умногоме већа - у првом плану је искуство библиотекара које му омогућава да, упознат са проблемима пацијента, одабере адекватну литературу која ће произвести благотворан учинак, јер лош одабир литературе код пацијента може изазвати негативан ефекат. Развојна библиотерапија је мање формалног карактера јер подразумева групне активности у

12 Љиљана Симић, „Улога библиотеке у библиотерапији”, http://www.vma.mod.gov.rs (преузето 10. 8. 2021). 
којима појединци добровољно учествују. Реализацијом развојне терапије, као видом помоћи да се појединци изборе са стресогеним факторима, испољава се превентивна страна библиотерапије, јер циљ је предупредити стања која могу настати као резултат кризних ситуација у којима се особа налази. Улога библиотекара у процесу развојне библиотерапије подразумева избор одговарајуће литературе у складу са терапијским захтевима, јер се пажња посвећује дискутовању о прочитаном. Библиотекар и терапеут креирају списак, условно, позитивних и негативних књига. Због тога што јој је тежиште група, развојна библиотерапија погодна је за реализацију са децом, старим лицима, зависницима, затвореницима и сл. групама.

\section{Соционичка типологија читалаца и типологија књига}

Упркос чињеницама да су током развоја цивилизације библиотеке имале повлашћено место у духовном развоју човечанства, као и да су стари народи на читање гледали као на процес којим се исцељују и дух и тело, библиотерапија, као грана библиотекарства, званично је призната тек у 20. веку.

Усвојивши из психијатрије, односно психотерапије методологију, библиотерапија доприноси, преко прочитаног, позитивним ефектима на психичку сферу човека. „Ствар је у томе да психотерапија и њена теорија, методе и поступци не само да прожимају библиотерапеутске радње него се интуитивно и примењују у библиотекама."13 Осврнемо ли се на злайна иравила која је формулисао отац индијског библиотекарства Шијали Рамамарита Ранганатана, на којима почива библиотечка делатност, јасно је да иманентна одлика библиотеке брига о кориснику. „Према томе, библиотекар мора бити свестан да му је дата огромна друштвена одговорност, коју може успешно испунити једино ако у потпуности схвати когнитивне процесе у друштву и ако то знање преточи у ефикасне услуге корисницима."14 Диференциран приступ кориснику императив је библиотерапије, па је отуда у нераскидивој вези са библиопсихологијом. Према мишљењу Н. А. Рубакина, књиге, као и људи, поседују одређене типске одлике. Рубакин је упућивао библиотекаре на важност да типове читалаца дефинишу према типовима личности - индуктиван, дедуктиван, синтетички, аналитички, емоционалан итд. „Увек пада у очи да човек чита неку књигу ради

\footnotetext{
Исто.

14 Гордана Стокић, Ка филозофији библиоиеккарсиива (Панчево: Мали Немо, 2017), 72.
} 
хармонизације најрањивије стране свога Ја. Свака личност је непоновљива, али и типична. Омиљена књига такође припада одређеном типу. Њу је написао аутор који и сам припада одређеном психолошком типу. У њој делују личности које су представници различитих типова." ${ }^{15}$ Јасно је да ће читалац, попут огледалског одраза, бирати књигу или аутора који су подударни одликама психолошког типа коме и сам припада.

У схватању типологије читалаца од велике је помоћи соционика млада наука изникла на конкретизацији и надоградњи учења о психолошким типовима Карла Густава Јунга. Литванка, А. Аугустинавичјуте је 1978. године утемељила соционику као науку усавршивши Јунгову типологију, при чему је установила моделе шеснаест соционичких типова и интертипских односа. Ауторка је, конкретизујући Јунгову поделу на интроверте и екстроверте и основне психолошке функције - мишљење, осећање, интуиција, опажање - као крајњи продукт добила типове личности у законитости дуалитета: 1. интуитивно-логички екстроверт, 2. сензорно-етички интроверт, 3. етичко-сензорни екстроверт, 4. логичко-интуитивни интроверт, 5. етичко-интуитивни екстроверт, 6. логичко-сензорни интроверт, 7. сензорно-логички екстроверт, 8. интуитивно-логички интроверт, 9. логичко-интуитивни екстроверт, 10. етичко-сензорни интроверт, 11. сензорно-етички екстроверт, 12. интуитивно-логички интроверт, 13. логичко-сензорни екстроверт, 14. етичко-интуитивни интроверт, 15. интуитивно-етички екстроверт, 16. сензорно-логички интроверт. ${ }^{16}$

По узору на учење А. Аугустинавичјуте, Јелена Николајевна Исајева предлаже дефинисање нових термина - соционичка библиопсихологија (библиосоционика) и соционичка библиотерапија (социобиблиотерапија) - као и њихову конкретну имплементацију у библиотечку праксу. Када је у питању практична примена соционике у библиотекама, замисао је да „у анотацијама уметничких (и научно-популарних) дела треба уносити информацију о социотиповима аутора и главног јунака, о степену оптимистичности сижеа, препоруку: за које социотипове и за које библиосоционичке и социобиблиотерапеутичке сврхе је дата књига корисна". ${ }^{17}$ Исајева излаже идеју о формирању соционичке картотеке, унутар које препоручује картотеку пожељних жанрова, као и формирање соционичког модела

15 Јелена Николајевна Исајева, „О соционичкој библиопсихологији и соционичкој библиотерапији", у Библиоиекка као оілеgало Васељене, приредио Добрило Аранитовић (Београд: Службени гласник, 2009), 545.

16 Више о томе: Јелена Николајевна Исајева, „О соционичкој библиопсихологији...”, 543-556.

17 Јелена Николајевна Исајева, „О соционичкој библиопсихологији...”, 552. 
смештања књига на посебне полице унутар којих би постојала класификација према одговарајућим социотиповима. Према њеном мишљењу, соционичка библиотерапија је благотворна за све људе без изузетка. Суштина интертипских односа огледа се у препознавању типског двојника, стога се, у стањима психолошке дисхармоније, може препознати која књига коме читаоцу треба бити „прописана” у конкретној ситуацији. Попут типова личности, препознају се и типови књига: ${ }^{18}$ акииивационе су оне књиге које у тренуцима малодушности делују подстицајно, иgенииччне књиге помажу у саморазумевању, оїлеgалске књиге позитивно утичу код стања неспокојства или осећаја инфериорности, књиге йреgајници уче смислу живота, књиге контиролори утичу на карактерне особине, док се књиге конфликйори и ойоненйи квалификују као стресогени фактори и, пожељно је, овакве књиге одстранити из процеса социобиблиотерапије.

\section{Делотворност библиотерапије}

Неретко се људи у тражењу начина за превладавање стања изазваних стресом за помоћ обраћају библиотекару. Већ су споменута благотворна дејства читања на људску психу, али ваља подсетити на човекову потребу за лепим, а управо читање књижевних дела има активан утицај на афективну сферу човековог бића. Књига је „лек” који, сем специјализованих стручњака, можемо сами себи прописати. Поред терапеутског читања у сврху психофизичког бољитка, библиотерапија може бити и лишена овог циља - читање може бити циљ да се поправи расположење или мисли скрену од свакодневних размишљања о проблемима. Исправно одабрана књига готово исто је важна као правилно одабран лек. „Библиотерапија као ефективна технологија психокорекције емоционалног стања и стицања новог, адекватног модела понашања користи се у раду (како с децом тако и с одраслима) с циљем интеграције личности, развоја стваралачких способности и адаптивних навика, а такође и с циљем усавршавања начина комуникације с околином."19

Адекватан одабир литературе у примени библиотерапије од пресудног је значаја за њену ефикасност. У „Приручнику за психотерапију” А. J.

18 Јелена Николајевна Исајева, „О соционичкој библиопсихологији...”, 552.

19 Наталија Томовна Оганесјан, „Библиотерапија као средство корекције психичких стања личности", у Библиоиекка као оїлеgало Васељьене, приредио Добрило Аранитовић (Београд: Службени гласник, 2009), 558. 
Алексејчик излаже списак књижевних жанрова, ${ }^{20}$ конципиран по степену важности за успешну библиотерапију. Првостепени значај припада специјалној медицинској литератури која има циљ да читаоцу пружи осећај контроле и смирености кроз сазнања која нуди. Филозофска и духовна литература помажу у разумевању света и пре/осмишљавању властитог живота. Биографска и аутобиографска књижевност мора бити заступљена у свакој библиотеци зарад позитивних ефеката које производи кроз примере савладавања животних тешкоћа људи чије животе описује. Алексејчик овај жанровски низ наставља класичном руском књижевношћу, критичком литературом и публицистиком, хумористичком и сатиричном књижевношћу истичући благотворни утицаје позитивних осећања које сваки од жанрова побуђује код читаоца. Фолклор, бајке, научнофантастична књижевност, детективски роман, драмска дела, преко педагошке, правне и уско стручне литературе, такође су се нашли на списку пожељних жанрова за примену у библиотерапији.

Учинковитост примене библиотерапије $\mathrm{e}^{21}$ је многострука. Позийивни емоционални gоживљаји које побуђује прочитана књига могу ублажити последице стреса и фрустрација. Уйознаваюе са варијанйама решења помаже човеку код проналажења алтернативних решења за властите проблеме. Сматра се да уколико је читалачко искуство богатије, могућности које пружа библиотерапија су сразмерно веће. Поистиовећиване са јунаком къижевноі gела или идентификација, читаоца ставља пред сазнање да није усамљен у својим осећањима или у конкретној ситуацији, већ да су и други искусили исто што и он. „Тежња за поистовећивањем поприма утолико већу напетост уколико се лик јунака у асоцијацијама читаоца поклапа с његовом представом о 'суперличности' схваћеној као својеврсна идеална варијанта себе." 22 Вредност уметничке књижевности огледа се и у уйозна-

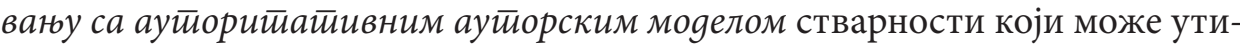
цати на преобликовање личности. Сугестија да је књига написана за било ког читаоца gелује на инgивияуално несвесно јер је ослобођена императива да је књига написана за конкретну помоћ конкретној особи. Буђене емйа$\bar{u}$ ије свакако је један од примарних учинака читања. Терапеутски ефекат

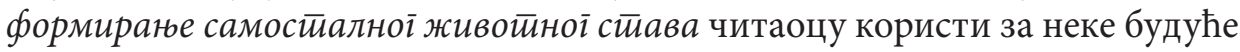

20 Више о томе: Н. В. Аверјанов, „Лек за душу: примена библиотерапије у библиотеци”, превод Гордана Стевић, Корак библиоиеке 2, 2 (2017): 128-148.

21 Више о томе: Наталија Томовна Оганесјан, „Библиотерапија као средство корекције психичких стања...”, 557-563.

22 Исто, 559. 
животне конфликте. Добре стране читања огледају се и у ефектима као што су уздизане ирроблема на свесни ниво вербализацијом или избавльане og емоционалних ироблема исйовешћу. Такође, терапеутска интеракција са уметношћу иницира формиране нових облика оgноса иррема сииварностии. „Уметност има, дакле, низ превентивних функција у друштву, повезаних са регулацијом емоционалне равнотеже. [...] Уметност преузима на себе вишак утисака спољашњег света који нису дошли до изражаја у спољашњим поступцима. Самим тим она смањује претерану напетост упијајући неостварени део живота нашег нервног система." ${ }^{23}$

\section{Закључне напомене}

Истражујући тему библиотерапије показало се да код нас не постоји велики број аутора који се њоме баве. Стога, на овом месту ваља споменути тестове из домена библиотекарства који проблематизују терапију читањем, а чија је ауторка Јелена Бенић - „Психолошки аспекти библиотечке делатности” и „Интердисциплинарност у библиотекарству”. Ауторка покреће питања образовања и стручног усавршавања библиотекара наводећи да се у Србији занемарује психолошка компонента библиотечког посла. Јелена Бенић истиче да код нас постоје само два акредитована семинара посвећена психолошком аспекту библиотекарства - један је сама осмислила, док је Јелена Јовин ауторка другог. Са медицинског аспекта питањем библиотерапије бавила се Маја Радановић, скрећући пажњу на позитивни учинак примене библиотерапије на лечење депресије. Проблем недостатка литературе који тематизује библиотерапију имплицира питање њене примене. За разлику од земаља у којима се примењује библиотерапија, једини пример овакве праксе код нас сведочи текст „Улога библиотеке у библиотерапији" Љиљане Симић која констатује да код нас постоји мали број здравствених установа и библиотека у којима постоји интересовање за спровођење библиотерапије. Као позитивне примере наводи болничку библиотеку Златиборског округа, огранак градске Библиотеке „Вук Караџић” у Пријепољу која је у оквиру установе неуропсихијатрије отворила свој огранак, као и Институт за ментално здравље у Београду. „Код нас се библиотерапија у оквиру миље терапије спроводи на Институту за ментално здравље у Београду, у Дневној болници за адолесценте. Поред групне

23 Исто, 562. 
и породичне психотерапије, терапијске заједнице, радне и арт терапије и фитнеса, примењује се и библиотерапија која обухвата планско читање и психолошку обраду одговарајуће литературе и текстова у третману особа са емоционалним или менталним тешкоћама." ${ }^{24}$ Сем ових скромних и драгоцених примера библиотерапије пронађених у тексту Љиљане Симић, на помињање сличних примера праксе у нашој земљи нисмо наишли.

Примена библиотерапије у раду библиотека вероватно би утицала на њену друштвену улогу, нарочито у времену у коме је култура читања упитна и у коме се тежи стварању библиотека без књига. Упркос новим технологијама које прихвата, „библиотекарство може да се наметне своме окружењу једино ако се врати испуњењу оних задатака по којима се увек разликовало од свих других делатности“. Библиотерапијска пракса могла би ревитализовати готово сакралну, архетипску улогу књиге и библиотеке - исцељење душе.

24 Љиљана Симић, „Улога библиотеке у библиотерапији”, http://www.vma.mod.gov.rs (преузето 10. 8. 2021). 


\section{Literatura i izvori:}

1. Averjanov, N. V. „Lek za dušu: primena biblioterapije u biblioteci”, prevod Gordana Stević. Korak biblioteke 2, 2 (2017): 128-148. (на ћирилици)

2. Aristotel. O pesničkoj umetnosti. Beograd: Prosveta, 1982. (на ћирилици)

3. Benić, Jelena. „Interdisciplinarnost u bibliotekarstvu. Glasnik Narodne biblioteke Srbije 16, 19 (2017): 9-20. (на ћирилици)

4. Benić, Jelena. „Psihološki aspekti bibliotečke delatnosti”. Glasnik Narodne biblioteke Srbije 15, 18 (2016): 173-184. (на ћирилици)

5. Isajeva, Jelena Nikolajevna. „O socioničkoj bibliopsihologiji i socioničkoj biblioterapiji”. U Biblioteka kao ogledalo Vaseljene, priredio Dobrilo Aranitović, 543-556. Beograd: Službeni glasnik, 2009. (на ћирилици)

6. Oganesjan, Natalija Timovna. „Biblioterapija kao sredstvo samoaktuelizacije psihičkih stanja”. U Biblioteka kao ogledalo Vaseljene, priredio Dobrilo Aranitović, 531-542. Beograd: Službeni glasnik, 2009. (на ћирилици)

7. Oganesjan, Natalija Tomovna, „Biblioterapija kao sredstvo korekcije psihičkih stanja ličnosti”. U Biblioteka kao ogledalo Vaseljene, priredio Dobrilo Aranitović, 557-563. Beograd: Službeni glasnik, 2009. (на ћирилици)

8. Pandurević, Jelenka, Maja Anđelković. Kratka istorija pisma, knjige i biblioteka. Banja Luka: Univerzitet u Banjoj Luci, Filološki fakultet, Narodna i univerzitetska biblioteka Republike Srpske, 2014. (на ћирилици)

9. Radanović, Maja. „Biblioterapija kao edukativna i terapijska alatka i prikaz portretisanja psiholoških fenomena u jednom književnom delu, sa posebnim osvrtom na depresiju”. Timočki medicinski glasnik 40, 2 (2015): 106-110.

10. Simić, Ljiljana. „Uloga biblioteke u biblioterapiji”, http://www.vma.mod.gov.rs (preuzeto 10. 8. 2021). (на ћирилици)

11. Stokić, Gordana. Ka filozofiji bibliotekarstva. Pančevo: Mali Nemo, 2002.

12. https://covers4all.ru/mk/krovotecheniya/chitat-onlain-moi-alkogolizm (pristupljeno 23. 10. 2021).

13. https:/hr.pour-femme.org/8887667-book-therapy-a-book-will-save-our-lives-findout-how (pristupljeno 23. 10. 2021).

14. https://hr.griego-medical.com/vzaimosvjaz-psihicheskih-sostojanij-i-povedenija. htm (pristupljeno 23. 10. 2021).

15. http://psihokomunikacije.com/zanimljivi-tekstovi/sta-je-to-lekovito-citanje-ili-biblioterapija/ (pristupljeno 23. 10. 2021).

16. https://stil.kurir.rs/lifestyle/zanimljivosti/146015/biblioterapija-kako-knjige-pomazu-u-lecenju-mentalnih-poremecaja (pristupljeno 23. 10. 2021). 


\author{
Danica Savić \\ University Library, Kragujevac \\ danica.savic@uni.kg.ac.rs
}

\title{
THE ORIGIN, DEVELOPMENT, AND SIGNIFICANCE OF BIBLIOTHERAPY
}

\begin{abstract}
Summary: The paper aims to synthesize the available texts that problematize bibliotherapy as an auxiliary therapeutic method scientifically recognized only in the twentieth century. Also, in addition to defining the term, it presents the importance of bibliotherapy on the transformation of personality, as well as the role of therapists/ librarians in the process of treatment with books. The paper emphasizes the results of socionics, which additionally complements the bibliotherapeutic method with knowledge about the types of readers based on Jung's typology of personality. Similar to personality types, there are different book types within bibliotherapy that enable an individualized approach in the treatment process. Different types of bibliotherapy - institutional, clinical, and developmental - jointly performed by medical and library experts are presented and described. The paper presents multiple positive effects of bibliotherapy, from psychocorrection of emotional state, through creative and adaptive habits, to improvement of communication with others. Also, domestic authors who have so far contributed to the study of this topic are listed.
\end{abstract}

Keywords: concept of bibliotherapy, institutional bibliotherapy, clinical bibliotherapy, developmental bibliotherapy, socionics, types of readers, types of books, bibliotherapy literature, effectiveness of bibliotherapy.

Примљено: 8. септембра 2021.

Исправке: 23. октобра 2021.

Прихваћено: 5. новембра 2021. 